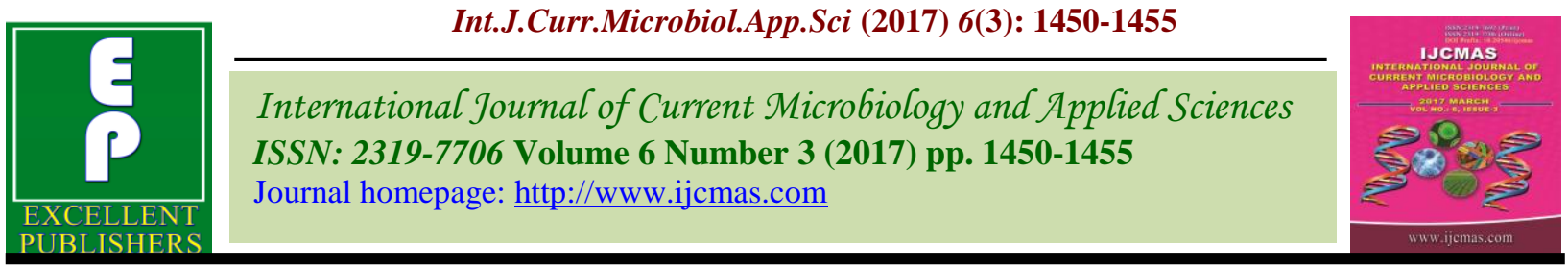

Original Research Article

https://doi.org/10.20546/ijcmas.2017.603.165

\title{
Efficacy of Fungicides and Biocontrol Agents against Fusarium oxysporum f.sp. ciceri
}

\author{
Praful Kumar* and S.S. Mane
}

\author{
Department of Plant Pathology, Dr. Panjabrao Deshmukh Krishi Vidyapeeth, \\ Akola, MS 444104, India \\ *Corresponding author
}

\begin{tabular}{|c|c|}
\hline & A B S T R A C T \\
\hline $\begin{array}{l}\text { Ke y w o r d s } \\
\text { Fusarium } \\
\text { oxysporum f. sp. } \\
\text { ciceri, Fungicides, } \\
\text { Biocontrol agents, } \\
\text { Efficacy, In vitro. }\end{array}$ & \multirow{3}{*}{$\begin{array}{l}\text { The present study was conducted under In vitro condition to examine effectiveness } \\
\text { of four fungicides (viz. Thiram @0.3\%, Carbendazim @ } 0.1 \% \text {, Captan @ } 0.3 \% \text {, } \\
\text { fosetyl AL @ } 0.2 \% \text { ) alone and in combination of these fungicides and three } \\
\text { Biocontrol agents (viz. Trichoderma harzianum, T. viride and Pseudomonas } \\
\text { fluorescens) against Fusarium oxysporum f. sp. ciceri. Among these fungicides } \\
\text { Carbendazim @ } 0.1 \% \text {, Fosetyl AL @ } 0.2 \% \text {, Thiram+Carbendazim @ } 0.3 \% \text { and } \\
\text { Fosetyl AL+Carbendazim @0.3\% was found the most effective with absolute } \\
\text { (100\%) inhibition of mycelial growth of Fusarium oxysporum f.sp. ciceri. } \\
\text { Whereas, Captan @ } 0.3 \% \text { was less effective with } 80.82 \% \text { and } 82.59 \% \text { inhibition of } \\
\text { mycelial growth respectively at } 5 \text { DAI and } 7 \text { DAI. Among three biocontrol agents, } \\
\text { Trichoderma harzianum show highest per cent inhibition of mycelial growth } \\
(66.67 \% \text { and } 72.96 \% \text { ) respectively at } 5 \text { DAI and } 7 \text { DAI. }\end{array}$} \\
\hline Article Info & \\
\hline $\begin{array}{l}\text { Accepted: } \\
\text { 22 February } 2017 \\
\text { Available Online: } \\
20 \text { March } 2017\end{array}$ & \\
\hline
\end{tabular}

Introduction

Chickpea (Cicer arietinum L.) is an important pulse crop and it is used as a big source of protein in the human diet. Chickpea was originated from West Asia and now cultivated in 55 countries of the world. India ranks first in the world in terms of the acreage cultivated and the annual yield. In India, chickpea is grown in 8.82 Mha with a total production of $8.35 \mathrm{M}$ tonnes and an average productivity of $947 \mathrm{~kg} / \mathrm{ha}$ (Agriculture Statistics at a Glance, 2015).

Annual yield losses in chickpea were estimated to be 4.8 million tones worldwide due to biotic stresses, including infectious plant diseases (Ryan, 1997).
Fusarium wilt caused by Fusarium oxysporum f. sp. ciceri (Padwick) Matuo and K. Sato, is considered most serious and widespread disease of chickpea throughout the chickpea growing areas of the world (Jalali and Chand, 1992). The wilt infection can damage the crop completely and cause $100 \%$ yield loss under severe conditions (Navas-Cortes et al., 2000; Halila and Strange, 1996).

The chickpea wilt fungus Fusarium oxysporum f. sp. ciceris is a vascular pathogen. This pathogen is soil borne (Singh et al., 2009) and seed borne (Haware et al., 1978). It can survive in soil, even in the absence of a host for 3-6 years (Ayyub et al., 
2003; Haware et al., 1996). The spores of fungus enter in the plants passing through the roots. When the spores reach in vascular system they produce certain enzymes that digest the cell walls and obstruct the plants transport system. Discoloration occurs inside vascular tissues from the roots to the aerial parts. Yellowing and wilting of the foliage occurs and finally there is necrosis (Brayford, 1998; leslie and Summerell, 2006). Relatively high temperature with drought may cause upto $80 \%$ plant mortality (Govil and Rana, 1994). As a result of wilt infection, the complete plant or plant parts may die within few weeks of infection. In field conditions, the typical wilting can be appeared within 3-4 weeks after sowing, if the variety is susceptible (Haware, 1990).

Several measures such as use of resistant cultivars, cultural practices, use of chemicals and bio-control agents, are taken by growers but control is not satisfactory. Although each of these methods of disease management practices has their own importance, yet none is completely successful when applied alone for disease control (Chandel and Deepika, 2010). Despite many attempts to control chickpea wilt fungus, the problem is still important throughout the world. The chemical control based on the use of fungicides is most effective and reliable method. Biological control is a potential alternative to chemical fungicides (Parker et al., 1985). The uses of Trichoderma as a bioagent have attracted attention because of its effectiveness against various plant pathogens and for its growth promoting action (Harman et al., 2004). The Trichoderma species evaluated against the wilt pathogen exhibited great potential in managing chickpea wilt under glass house and field conditions (Dubey et al., 2007). Selected isolates of Pseudomonas fluorescens were found to be effective in reducing the wilt incidence and increasing the plant growth as well as grain yield of chickpea (Liu et al., 2007).

\section{Materials and Methods}

The studies were carried out under In vitro conditions. All the isolation and inoculation work were carried out in laminar air flow under aseptic condition. The platform of laminar air flow was sterilized by glowing ultraviolet light for half an hour prior to commencement of work.

The working surface of laminar flow and side glasses were surface sterilized with denatured spirit. Moreover, other such necessary care was taken to maintain and carryout work under aseptic condition. The glass wares such as Petri plates, pipettes, beakers and test tubes were sterilized in hot air oven at $180^{\circ} \mathrm{C}$ for 1 hour and media were sterilized in autoclave at $121.6{ }^{0} \mathrm{C}, 15 \mathrm{lbs} /$ inch $^{2}$ for 15 minutes.

\section{Isolation of Fusarium oxysporum f.sp. ciceri}

Chickpea plant showing typical wilt symptoms were collected from the field of Pulses Research Unit, Dr. Panjabrao Deshmukh Krishi Vidyapeeth, Akola (M.S). The repeated isolations were made to isolate pathogen from wilted plants showing browning of vascular tissue. The roots and stem of infected plants were washed in running tap water to remove soil before isolation to avoid contamination.

The roots were cut into small bits of the size $2.5 \mathrm{~mm}$, with sterilized blade. These bits were then surface sterilized with 0.1 per cent mercury chloride for two minutes and washed with three changes of sterilized water to remove traces of mercury chloride. Each bit was blot dried and four bits placed on the each prepoured solidified potato dextrose agar (PDA) plates. These plates were then incubated at $27 \pm 2{ }^{0} \mathrm{C}$ for seven days. The fungal growth was transferred to the plates of PDA. 


\section{Purification, identification maintenance of pathogen}

Fusarium oxysporum f.sp. ciceri culture isolated from wilted chickpea plant were purified from single spore method and identified by the colony characteristics appeared as white cottony growth on PDA medium which became felted and wrinkled in old culture colonies. By microscopically their morphological characteristics such as abundance of micro and fewer macro conidia were analysed. Microconidia were oval to cylindrical, straight to curved and measured 2.5-3.5 x 5-11 $\mu \mathrm{m}$ and were produced on short, unbranched monophialides. Macroconidia borne on branched conidiophores, were thin walled, 3-5 septate, fusoid and pointed at both ends and 3.5-4.5 x 25-65 $\mu \mathrm{m}$ (Trivedi and Rathi, 2015).

The pathogen was subcultured on PDA slants and allowed to grow at $27 \pm 2^{0} \mathrm{C}$ temperature for 10 days. Obtained culture was stored in refrigerator at $4^{0} \mathrm{C}$ and were sub cultured periodically once in a month.

\section{Evaluation of fungicides against Fusarium oxysporum f.sp. ciceri}

To evaluate the effect of fungicides against Fusarium oxysporum f.sp ciceri "Poison Food Technique" was used. The requisite amount of each fungicide based on active ingradient was added to an autoclaved potato dextrose agar to obtain the desired concentrations of all fungicides. The same medium without the fungicide served as control. The medium was poured into $90 \mathrm{~mm}$ Petri plates in 3 replicates and after solidification, each plate was inoculated with a $5 \mathrm{~mm}$ mycelial disc of test fungus. The inoculated Petri plates were incubated at $27 \pm 2^{0} \mathrm{C}$. After incubation, radial growth was measured at 5 DAI and 7 DAI. Per cent growth inhibition was calculated by applying the following formula (Vincent, 1947).
Per cent inhibition $=\frac{\mathrm{C}-\mathrm{T}}{------} \times 100$

Where,

$\mathrm{C}=$ Growth of test fungus in control in $\mathrm{mm}$

$\mathrm{T}=$ Growth of test fungus in treatment in $\mathrm{mm}$

Evaluation of biocontrol agents against Fusarium oxysporum f. sp. ciceri

The studies on antagonism between $F$. oxysporum f. sp. ciceri and the fungal antagonists viz., Trichoderma viride, $T$. harzinaum were carried out by applying 'Direct Bit Placement Method' (Brodbent et al., 1971). Solidified PDA medium in the plates was inoculated by placing the discs ( 5 $\mathrm{mm}$ diameter) of biocontrol agents culture and exacting opposite to this disc of test fungus ( 7 days old culture) were placed in such a manner that both organisms would get equal opportunity for their growth. Antagonism between $F$. oxysporum f. sp. ciceri and Pseudomonas fluorescens was carried out by dual culture method (Dubey et al., 2015). Nutrient agar medium (15 ml) was poured in each Petri dish $(90 \mathrm{~mm}) .7$ days old inoculum ( $5 \mathrm{~mm}$ disc) of $F$. oxysporum f. sp. ciceri was placed in the centre and 3 days old inoculum of bacteria were streaks at both sides of the inoculum of the pathogen. The control Petri dishes were inoculated only with the pathogen (Dubey et al., 2015). Plates were incubated at $27 \pm 2^{\circ} \mathrm{C}$. The growth of Fusarium oxysporum f.sp ciceri was measured and the per cent growth inhibition was calculated as per following the formula (Vincent, 1947).

$\mathrm{X}-\mathrm{Y}$
Per cent growth Inhibition $=--------\times 100$

Where,

$\mathrm{X}=$ the mycelial growth of the pathogen $(F$. oxysporum $f$. sp. ciceri) in the absence of antagonist.

$\mathrm{Y}=$ the mycelial growth of the pathogen $(F$. 
oxysporum $f . s p$. ciceri) in the presence of the antagonist.

\section{Results and Discussion}

Evaluation of fungicides against Fusarium oxysporum f.sp. ciceri

Based on in vitro efficacy against Fusarium oxysporum f. sp. ciceri, the result (Table 1) concluded that among all the 4 fungicides alone and their combination, Carbendazim, Fosetyl AL, Thiram+Carbendazim and Fosetyl AL+Carbendazim at given concentration were found to be significantly superior over control in inhibition $(100 \%)$ the radial growth and sporulation of Fusarium oxysporum f. sp. ciceri at 5 DAI and 7 DAI. This results are in conformity with Dubey et al., (2015) found the fungicide Bavistin (Carbendazim) inhibited $100 \%$ mycelium growth of Fusarium oxysporum f.sp ciceri, Maitlo et al., (2014) reported Aliette (Fosetyl AL) fungicide was effective against Foc, Poddar et al., (2004) reported that the use of systemic fungicide Carbendazim was effective against Fusarium oxysporum in chickpea.

Table.1 Effect of fungicides on growth of Fusarium oxysporum f.sp. ciceri

\begin{tabular}{|c|c|c|c|c|c|c|}
\hline \multirow[b]{2}{*}{$\begin{array}{l}\text { Treatme } \\
\text { nts }\end{array}$} & \multirow[b]{2}{*}{ Fungicides } & \multirow[b]{2}{*}{ Concentration } & \multicolumn{2}{|c|}{5 Days after incubation } & \multicolumn{2}{|c|}{7 Days after incubation } \\
\hline & & & $\begin{array}{c}\text { Mean } \\
\text { colony } \\
\text { diameter } \\
(\mathbf{m m})\end{array}$ & $\begin{array}{c}\text { Per cent } \\
\text { growth } \\
\text { inhibition }\end{array}$ & $\begin{array}{c}\text { Mean } \\
\text { colony } \\
\text { diameter } \\
(\mathbf{m m})\end{array}$ & $\begin{array}{c}\text { Per cent } \\
\text { growth } \\
\text { inhibition }\end{array}$ \\
\hline $\mathrm{T}_{1}$ & Thiram & $0.3 \%$ & 11.17 & $\begin{array}{c}83.92 \\
(66.36)^{*}\end{array}$ & 12.83 & $\begin{array}{c}85.74 \\
(67.81)^{*}\end{array}$ \\
\hline $\mathrm{T}_{2}$ & $\begin{array}{c}\text { Carbendazim } \\
50 \% \mathrm{WP}\end{array}$ & $0.1 \%$ & 0.00 & $\begin{array}{c}100 \\
(90.00)^{*}\end{array}$ & 0.00 & $\begin{array}{c}100 \\
(90.00)^{*}\end{array}$ \\
\hline $\mathrm{T}_{3}$ & $\begin{array}{c}\text { Captan } \\
50 \% \mathrm{WP}\end{array}$ & $0.3 \%$ & 13.33 & $\begin{array}{c}80.82 \\
(64.03) *\end{array}$ & 15.67 & $\begin{array}{c}82.59 \\
(65.34)^{*}\end{array}$ \\
\hline $\mathrm{T}_{4}$ & $\begin{array}{c}\text { Fosetyl AL } \\
80 \% \mathrm{WP}\end{array}$ & $0.2 \%$ & 0.00 & $\begin{array}{c}100 \\
(90.00)^{*}\end{array}$ & 0.00 & $\begin{array}{c}100 \\
(90.00)^{*}\end{array}$ \\
\hline $\mathrm{T}_{5}$ & Thiram + Captan & $0.3 \%(1: 1)$ & 11.00 & $\begin{array}{c}84.17 \\
(66.55)^{*} \\
\end{array}$ & 11.67 & $\begin{array}{c}87.03 \\
(68.89) * \\
\end{array}$ \\
\hline $\mathrm{T}_{6}$ & $\begin{array}{c}\text { Thiram + } \\
\text { Carbendazim }\end{array}$ & $0.3 \%(2: 1)$ & 0.00 & $\begin{array}{c}100 \\
(90.00)^{*}\end{array}$ & 0.00 & $\begin{array}{c}100 \\
(90.00)^{*}\end{array}$ \\
\hline $\mathrm{T}_{7}$ & $\begin{array}{l}\text { Fosetyl AL + } \\
\text { Carbendazim } \\
\end{array}$ & $0.3 \%(1: 1)$ & 0.00 & $\begin{array}{c}100 \\
(90.00)^{*}\end{array}$ & 0.00 & $\begin{array}{c}100 \\
(90.00)^{*}\end{array}$ \\
\hline $\mathrm{T}_{8}$ & Control & & 69.50 & 0.00 & 90.00 & 0.00 \\
\hline F test & & & & Sig & & Sig \\
\hline $\mathrm{SE}(\mathrm{m}) \pm$ & & & & 0.134 & & 0.086 \\
\hline $\begin{array}{c}\mathrm{CD} \\
(\mathrm{P}=0.01)\end{array}$ & & & & 0.705 & & 0.452 \\
\hline
\end{tabular}

$(*=$ Figures in parentheses indicates arc sin transformed value) 
Table.2 Antagonistic effect of bioagents on growth of Fusarium oxysporum f.sp. ciceri

\begin{tabular}{|l|l|c|c|c|c|}
\hline \multirow{2}{*}{ Treatments } & \multicolumn{2}{|c|}{ Bioagents } & \multicolumn{2}{|c|}{$\begin{array}{c}\text { 5 Days after } \\
\text { incubation }\end{array}$} & \multicolumn{2}{c|}{\begin{tabular}{c} 
7 Days after incubation \\
\cline { 2 - 5 }
\end{tabular}} & $\begin{array}{c}\text { Mean } \\
\text { colony } \\
\text { diameter } \\
(\mathbf{m m})\end{array}$ & $\begin{array}{c}\text { Per cent } \\
\text { growth } \\
\text { inhibition }\end{array}$ & $\begin{array}{c}\text { Mean } \\
\text { colony } \\
\text { diameter } \\
(\mathbf{m m})\end{array}$ & $\begin{array}{c}\text { Per cent } \\
\text { growth } \\
\text { inhibition }\end{array}$ \\
\hline $\mathrm{T}_{1}$ & $\begin{array}{l}\text { Trichoderma } \\
\text { viride }\end{array}$ & 24.67 & $\begin{array}{c}64.50 \\
(53.43)^{*}\end{array}$ & 25.33 & $\begin{array}{c}71.85 \\
(57.96)^{*}\end{array}$ \\
\hline $\mathrm{T}_{2}$ & $\begin{array}{l}\text { Trichoderma } \\
\text { harzianum }\end{array}$ & 23.17 & $\begin{array}{c}66.60 \\
(54.70)^{*}\end{array}$ & 24.33 & $\begin{array}{c}72.96 \\
(58.67)^{*}\end{array}$ \\
\hline $\mathrm{T}_{3}$ & $\begin{array}{l}\text { Pseudomonas } \\
\text { fluorescens }\end{array}$ & 31.33 & $\begin{array}{c}54.90 \\
(47.81)^{*}\end{array}$ & 37.67 & $\begin{array}{c}58.15 \\
(49.69)^{*}\end{array}$ \\
\hline $\mathrm{T}_{4}$ & Control & 69.50 & 0.00 & 90 & 0.00 \\
\hline $\mathrm{F}$ test & & & Sig & & Sig \\
\hline $\mathrm{SE}(\mathrm{m}) \pm$ & & & $\mathbf{0 . 1 3 0}$ & & $\mathbf{0 . 0 9 2}$ \\
\hline $\mathrm{CD}(\mathrm{P}=0.01)$ & & & $\mathbf{1 . 3 9 8}$ & & $\mathbf{0 . 9 9 2}$ \\
\hline
\end{tabular}

$(*=$ Figures in parentheses indicates arc sin transformed value)

Evaluation of biological agents against Fusarium oxysporum f. sp. ciceri

Based on In vitro efficacy, the result (Table 2) indicated that among the 3 biocontrol agents, Trichoderma harzianum show highest per cent mycelial growth inhibition $(66.67 \%$ and $72.96 \%$ ) respectively at $5 \mathrm{DAI}$ and $7 \mathrm{DAI}$.

The antagonistic effect can be attributed to diffusible substances (antibiosis) secreted by the antagonist or due to their direct effect on the target pathogen. Effectiveness of Trihoderma harzianium against Fusarium oxysporum f. sp. ciceri has also been reported by Yadav et al., (2012) who established that T. harzianum was most effective against Fusarium oxysporum f. sp. ciceri (71.36\%).

\section{References}

Agricultural Statistics at a Glance. 2015. Directorate of Economics and Statistics, Department of Agriculture, Ministery of Agriculture, Goverment of India, New Delhi. pp 74.

Ayyub, M.A., Khan, S.M., Ahmad, M. and
Iftikhar, K. 2003. Screening of chickpea germplasm for the sources of resistance against chickpea wilt (Fusarium oxysporum f. sp. ciceris). Pak. J. Phytopathol., 15(1-2): 25-27.

Brayford, D. 1998. Fusarium oxysporum f.sp. ciceris. IMI Descriptions of Fungi and Bacteria. No. 1113.

Brodbent, P., Baker, K.F. and Waterworth, Y. 1971. Bacteria and actinomycetes antagonistic to fungal root pathogens in Australian soils. Austr. J. Biol. Sci., 24: 925-944.

Chandel, S. And Deepika, R. 2010. Recent advances in management and control of Fusarium yellows in Gladiolus species. $J$. Fruit Ornamental Plant Res., 18(2): 361380

Dubey S.C., Singh, V., Kumari, P., Upadhyay, B.K. and Singh, B. 2015. Combined application of Fungal and Bacterial bioagents, together with fungicide and Mesorhizobium for integrated Management of Fusarium wilt of chickpea. Int. Organization for Biol. Control, DOI 10.1007/s10526-015-9653-8

Dubey, S.C., Suresh, M. And Singh, B. 2007. Evaluation of Trichoderma species against 
Fusarium oxysporum f. sp. ciceri for integrated management of chickpea wilt. Biol. Control, 40: 118-127.

Govil, J.N. and B.S. Rana. 1994. Stability of host plant resistance to wilt (Fusarium oxysporum f. sp. ciceris) in chickpea. Int. J. Trop. Pl. Dis., 2: 55-60.

Halila, M.H. and Strange, R.N. 1996. Identification of the causal agent of wilt of chickpea in Tunisia as Fusarium oxysporum f. sp. ciceris race. Phytopath. Mediterr., 35: 67-74.

Harman, G.E., Howell, C.R., Viterbo, A., Chet, I. and Lorito, M. 2004. Trichoderma speciesopportunistic, avirulent plant symbionts. Nat. Rev., 2: 43-56.

Haware, M.P. 1990. Fusarium wilt and other important diseases of chickpea in the Mediterranean area. Options Mediterraneennes Serie A: Seminaires, 9: 63-166.

Haware, M.P., Nene, Y.L. and Rajeshwari, R. 1978. Eradication of Fusarium oxysporum f.sp.ciceris transplanted in chickpea. Seed Phytopathol., 68: 1364-1367.

Haware, M.P., Y.L. Nene and M. Natarajan. 1996. The survival of $F$. oxysporum f. sp. ciceris in the soil in the absence of chickpea. Phytopathologia Mediterranea, 35: 9-12.

Jalali, B.L. and Chand, H. 1992. Chickpea wilt. In: Plant Diseases of International Importance. Vol. I. Diseases of Cereals and Pulses, (Eds.): Singh, U.S., A.N. Mukhopadhayay, J. Kumar and H.S. Chaube. Prentice Hall, Englewood Cliffs, NJ. pp. 429-444.

Leslie, J.F. and Summerell, B.A. 2006. The Fusarium Laboratory Manual. Blackwell Publishing, State Avenue, Ames, Iowa, USA.

Liu, Y.F., Chen, Z.Y., Ng, T.B., Zhang, J., Zhou, M.G., Song, F.P. and Liu, Y.Z. 2007. Bacisubin, an antifungal protein with ribonuclease and hemagglutinating activities from Bacillus subtillis strain B916. Peptides, 28: 553-559.

Maitlo, S.A., Syed, R.N., Rustamani, M.A., Khuhro, R.D. and Lodhi, A.M. 2014. Comparative efficacy of different fungicides against fusarium Wilt of chickpea (Cicer arietinum L.). Pak. J. Bot., 46(6): 2305-2312.

Navas-Cortes, J.A., Hau, B. And Jimenez-Diaz, R.M. 2000. Yield loss in chickpeas in relation to development of Fusarium wilt epidemics. Phytopath., 90: 1269-1278.

Parker, C.A., Rovira, A.D., Moore, K.J. and Wong, P.T.W. 1985. Ecology and Management of Soil-borne Plant Pathogens. APS Press, St. Paul, MN, USA

Poddar, R. K., Singh, D.V. and Dubey, S.C. 2004. Management of chickpea wilt through combination of fungicides and bioagents. Indian Phytopath., 57(1): 39-43.

Ryan, J.G. 1997. A global perspective on pigeon pea and chickpea sustainable production systems-present status and future potential. In: Recent Advances in Pulses Research (Eds.): Asthana A.P. and Ali, M. Indian Society of Pulses Research and Development, Kanpur, India. pp. 1-31.

Singh, J., Ratan, V. and Singh, N. 2009. Management of wilt of chickpea. Annals Plant Prot. Sci., 17: 248-249.

Trivedi, L. and Rathi, Y.P.S. 2015. Detection of seed mycoflora from chickpea wilt complex seedborne Fusarium oxysporum f.sp. ciceri diseased seeds. World J. Pharma. and Pharmacl. Sci., 4(9): 1242-1249.

Vincent, J.M. 1947. Distoration of fungal hyphae in the presence of certain inhibitors. Nature, 15: 850 .

Yadav, S., Mane, S.S. and Ghawade, R.S. 2012. Efficacy of Herbicide, Fungicide and Biological control agents against chickpea wilt. PKV Res. J., 36(1).

\section{How to cite this article:}

Praful Kumar and Mane, S.S. 2017. Efficacy of Fungicides and Biocontrol Agents against Fusarium oxysporum f.sp. ciceri. Int.J.Curr.Microbiol.App.Sci. 6(3): 1450-1455. doi: https://doi.org/10.20546/ijcmas.2017.603.165 